\title{
Juvenile Delinquency in the Riverside Area of Banjarmasin South Kalimantan
}

\author{
Sulistiyana*, Ari Hidayat \\ Teaching and Education Science Faculty \\ Lambung Mangkurat University \\ Banjarmasin, Indonesia \\ *Sulis.bk@ulm.ac.id
}

\begin{abstract}
This article is about the identification of juvenile delinquency in the riverbank area of Banjarmasin, South Kalimantan. Banjarmasin is known as the City of a Thousand Rivers because it has many rivers which are used as settlements so most of the people. Currently there tends to be a lot of juvenile delinquency that occurs involving school-age children and they mostly live on riverbanks. One of the causes of juvenile delinquency is the weak resistance of adolescents to environmental influences. This research uses a descriptive qualitative method. Data source for BK teachers, students of SMPN 25 Banjarmasin who are in the riverbank area. The technique of collecting data is by observation, interview, and documentation. The results of this research are the types of delinquency found in students who live in riverbank areas, namely, drug use, liquor, free sex, stealing, physical and verbal bullying. supervision from parents and the surrounding environment, many students' parents work as casual labourers, factory workers, and their mothers work as household assistants so that there is very little guidance for children because of the focus on earning a living, lack of inculcation of religious values and moral values in the environment where adolescents grow and develop.
\end{abstract}

\section{Keywords-juvenile delinquency, the riverside area}

\section{INTRODUCTION}

Changes every time and the journey of this nation is on the shoulders of children, a child who is born and raised in a good environment with care and guidance, the love given by parents will give birth to an individual who has quality. Stepping on the transition period between children into adults is called adolescence. This period is a period of self - determination, this period arises a doubt to do the role that will be performed. Surely a teenager is no longer a child nor an adult. In adolescence, he begins to try to act and behave like an adult, for example smoking, drinking, using drugs, and engaging in sexual acts. This action is not in accordance with the norms or rules that apply to society. If it is left without control it can lead to crime. Crimes committed by juveniles or better known as juvenile delinquency [1].

Children as young people are the successors of the ideals of the nation's struggle and human resources for development.
Children as a form of long-term investment that cannot be ruled out its role to realize the life of the nation and state in all fields of life. Therefore, children need guidance, optimal physical, mental and spiritual guidance. Juvenile delinquency is not a new phenomenon of adolescence but a continuation of the pattern of asocial behaviour that begins in childhood. A social behaviour is influenced by parenting and communication in the family, therefore, is required an effective communication between children and parents since early stage. The role of communication within the family is very important for transferring values and culture [2]. Lack of intimacy of parents and adolescents, lack of parental involvement, lack of guidance, blame, and scolding adolescents can lead to juvenile delinquency behaviour [3]. The support of parents through communication and supervision is believed to reduce the use of drugs and juvenile delinquency [4]. Therefore, in the search for identity of adulthood, adolescents need parents who can guide them by using effective communication, so that messages are delivered properly and correctly. Adequate communication between parents and teens where children can express their opinions and feelings freely will effectively reduce the stress experienced of adolescents in their daily lives, so that it can establish a positive identity in adolescents [5]

As we know today, there are so many incidents of juvenile delinquency [6]. Various kinds of negative or deviant actions were carried out by some teenagers, which they seemed to think were just mediocre, let alone some who considered them to be something of pride. They often mention that this behaviour is merely a symbol of their courage, but this negative adolescent behaviour, many people consider it a very worrying behaviour for adolescents in Indonesia [7] including in the city of a thousand rivers, Banjarmasin, South Kalimantan, which is on the outskirts river. There have been many studies related to juvenile delinquency but no one has examined juvenile delinquency in the riverside area. This study aims to identify juvenile delinquency in the riverside area of Banjarmasin, South Kalimantan. 


\section{METHODS}

This research uses the descriptive qualitative method at SMPN 25 Banjarmasin which is located in the riverside area. The research instrument is the researcher himself. Data collection techniques used were interviews, observation, and documentation. Respondents as key informants were the principal, vice- principal, guidance and counselling teachers, subject teachers, students, parents, and stakeholders. Respondents from growing (snowball) to the data obtained saturated (redundancy). Data was analysed from the fieldwork carried out until the end of data collection, using data analysis techniques [8].

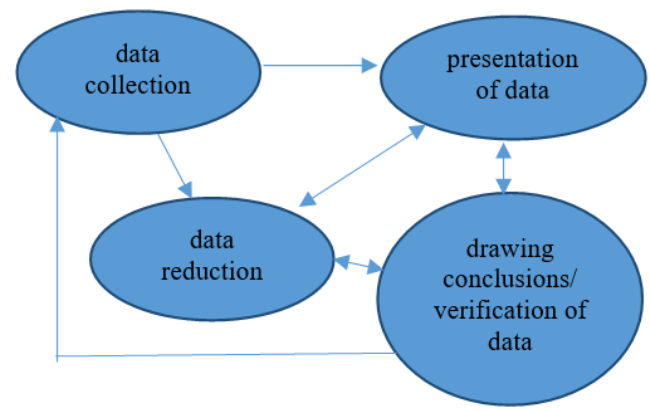

Fig. 1. Data analysis by Miles, Huberman and Saldana [8].

\section{RESULTS AND DISCUSSION}

\section{A. Results}

Informant Data, informants in this study were 5 informants who had been selected deliberately and in accordance with predetermined criteria, while the name of the research informant was initialized. This is done to protect the identity of the informant and also the type of crime committed. The following is the name of the informant who has been initialized AN who committed theft and used drugs, alcohol and was involved in fights and free sex. The hospital committed a crime of stealing, drinking, fighting. $\mathrm{AB}$ committed the crime of Stealing, drinking, fighting, casual sex. AR commits the crime of theft, using drugs, alcohol, fighting, casual sex. SV commits crimes using drugs, alcohol, fights, theft.

The information that the researchers obtained about juvenile delinquency in the riverbanks of the Banjarmasin, South Kalimantan is very meaningful and is one of the variables that must be seen, which is related to the activities of adolescents in the riverbank environment. On the other hand, age is also something that distinguishes a person's attitude and behaviour towards others. From the results of interviews with to 5 Informants are obtained that the age of the research informants is not too different between the five informants. The age range of informants was from 13-16 years, namely three informants aged 16 years, and two other informants aged 13-15 years. From the results of the interview, it was said that the youngest was 13 years old, and the oldest was 16 years old, amounting to three people.
Education is an important part for a person to be able to determine the quality of life, so that the level of education is one of the bases for one's behaviour. Education as a lifelong process of individual growth and development, in that process the interaction between individuals, individuals and the environment is beneficial for achieving optimal levels of individual development that can create the welfare of the ummah. Education can carry someone's knowledge. The results of the interview show that all informants are still educated (Junior High School), because the case study of this research is in (Junior High School) SMP 25 Banjarmasin, South Kalimantan. Education greatly influences a person for good things because in terms of knowledge, someone's education does not carry out deviant or delinquent behaviour, whereas someone with low education tends to often commit crimes.

Parents Overview Informant, family is the place where a child's initial development is, from the moment of his birth to the next process of physical and spiritual development. For a child, the family has a meaning and function that is vital for survival and in finding meaning and purpose in life. The following is an overview of the informants 'parents, namely the education, employment, and income of the informants' parents. The results of the research conducted by the researchers showed that two informant fathers had an elementary education (SD), there were two people, (Junior High School) there were two SMP and SMA (SMA) there was one person. Meanwhile, there were 3 informants with elementary school education, two junior high schools (SMP). And from the results of research conducted in the field, it can be seen that the work of the informants' parents is mostly factory workers, odd jobs, and domestic helpers. And the income of the informants' parents. From the results of the study, three parents of informants who have an income of more than Rp. 500,000- Rp. 800,000, parents of informants who work odd jobs, earn Rp. 400,000. From the research results, it can be seen that the informants 'parents' income ranges from IDR 500,000 - IDR 800,000 and at least IDR 400,000 per month, it is said to be underprivileged so that it is a link to children engaging in deviant behaviour.

Forms of juvenile delinquency in the riverbanks of Banjarmasin, South Borneo:

Theft is a form of juvenile delinquency which can be a criminal act. Stealing is taking the property of another person without the owner knowing it. As we all know stealing is haram. The following are the results of the researcher interviews with several research informants. The theft committed by these teenagers cannot be tolerated anymore, if there is no warning it can lead to criminal acts that make the environment unsafe and will disturb the community. They commit acts of theft due to the availability of money for snacks and to buy drinks and illegal drugs so that these children do not think long and justify any means to get money. There are those who steal in the school environment, such as when other students are not in the classroom and in school cooperatives. Outside the school environment such as in public places where they can steal. 
Narcotics are substances or drugs those derived from plants or non-plants, both synthetic and semi-synthetic, which can cause a decrease or change in consciousness, loss of taste, reduce to eliminate pain, and can cause dependence or very heavy addiction. Average teens who frequent going out at night and hanging out with his friends is easier to get addicted to drugs. This is because he feels defeated and does not hang out when his friends consume drugs and he does not. That is why many parents forbid their children not to go out at night except for educational reasons.

Liquor or alcoholic drinks are drinks containing ethanol, ethanol is a psychoactive substance and its consumption causes a loss of consciousness. At first, adolescents who practice drinking, in general, are trying to either give it by a friend or buy the drink themselves. Teens who drink alcohol are also caused by the nature of adolescents who are easily influenced by things that are positive or negative. This causes them to easily enter into negative things such as alcohol, smoking, and drugs. Teens doing alcoholic activities have their reasons, why they do alcoholic activities, as it is known their age is said to be the age that they are not allowed to drink alcohol, they say the reason is that they are reluctant to be with their friends, which is to appreciate their presence in the playgroup. They carry out liquor activities until late at night and are also accompanied by singing and singing. Sometimes making a fuss is like fighting, feeling the strongest, and most intense so that it triggers fights between teenagers. So that it causes people to be very restless with alcoholic behaviour.

Free sex that occurs and is experienced generally begins with dating. During this courtship period, teenagers began to have intimate relationships. When dating, they are tempted by flirtation, hug, and kiss, and when the fluctuation of lust is out of control it continues to have sexual relations. The place can be in a dark cinema, in a recreation area, boarding house, at home when the house is quiet, and even deliberately staying at a hotel. It is increasingly difficult for young women to evade when their boyfriend asks for proof of the sincerity of his love by having sex. This is what is often misunderstood among teenagers.

Causing a Racket. Apart from stealing the children, they always cause a commotion, such as fighting with friends in the neighbourhood. These children feel the strongest when their friends do not want to do what they want, such as forcing money to ask or harassing their female friends. By not thinking long, these children or adolescents can easily hit their friends. Like the female friend, these children committed indecent acts such as taking money, this crime was committed both within the school and outside the school environment. Because they could not stand the behaviour of their friends, the victims reported it to their parents, of course, the parents.

Factors that cause juvenile delinquency in the riverbank area of Banjarmasin, South Borneo:

Juvenile delinquency, which is a symptom of social deviance and pathology, can also be grouped in one class of social detective. The delinquency behaviour committed by adolescents can occur due to family factors, such as broken home families, the social environment, such as association with other adolescents who have committed delinquency, and the culture that has been embedded in that environment so that adolescents can fall into juvenile delinquency. This is very difficult to find a solution because the transition period of a teenager is very difficult to manage and it will be felt by every teenager. Teens who engage in delinquency generally lack selfcontrol or may abuse it. Juvenile delinquency behaviour can be caused by factors from the adolescent itself (internal) internal factors are factors that come from a person, be it genes, a depressed psychological state, personality defects, or a person's low spiritual level. Adolescent "naughty" behaviour can be caused by factors that exist within adolescents, namely weak self-control. Meanwhile, external factors from outside one's self, whether it is caused by disharmony from family, peers, and the influence of society and the mass.

\section{B. Discussion}

Forms of juvenile delinquency in the riverbanks of Banjarmasin, South Kalimantan, Theft, Narcotics, alcoholic drinks, free sex, and Causing a Racket. Regular mischief, such as like fighting, wandering, skipping school, leaving home without saying goodbye. Delinquency that leads to offenses and crimes such as riding a motorbike without a license, taking parental belongings without permission. Special delinquency such as narcotics abuse, sex outside of marriage, promiscuity, rape and others. This category is used as a measure of juvenile delinquency in the study [9].

Factors that cause juvenile delinquency in the riverbank area of Banjarmasin, South Kalimantan: Internal factors, is meant by factors internal factors are factors that come from the human body itself without being influenced by the environment. Personal factors, each child has a special personality, and special circumstances in this child can be a source of deviant behaviour. The internal factors that affect juvenile delinquency are: 1 . Age factor, 2 . Weak Self-Control

\section{Intelligence Factors}

External factors are factors, which comes from outside the child's body. This factor is often said to be the environmental factor in which the child is raised, namely: 1. Family Environment, 2. Community or Playgroup Environment/ Peers, 3. The Influence of Mass Media [10].

Behavioural deviations or illegal acts committed by children are caused by various factors, including the negative impact of rapid development, globalization in the field of communication, advances in science and technology, and changes in lifestyle and ways of life. As parents, it has brought about fundamental social changes in people's lives that greatly affect children's values and behaviour. In addition, children who lack or do not receive affection, care, guidance and guidance in developing attitudes, behaviour, adaptation, and supervision from guardian parents, or foster parents will easily be dragged into the flow of unhealthy and detrimental relationships in society and an environment personal 
development [11]. Social and cultural influences play a large role in the formation or conditioning of juvenile criminal behaviour. The behaviour of these adolescents shows signs of less or no conformity with social norms, the majority of which are juvenile delinquency in their early teens. In addition, marital disputes are related to interparental inconsistencies in parenting practices and how family conditions also affect juvenile delinquency [12].

The impact of juvenile delinquency crime can be wrong one impact of juvenile delinquency who is trapped in negative things is not impossible to choose the courage to commit a crime. Stealing money or robbing for valuables. The consequences of the mischief he does will have an impact on himself and are very detrimental to both physically and mentally, although this action can provide a pleasure but it is only a momentary pleasure. And it goes on as long as nothing is direct.

For families, the family will be embarrassed, communication between parents and children will be cut off, children will often be outside the home, and spend time with friends to have fun doing deviant deeds. The family will feel disappointed and ashamed of what was done by teenager [13].

\section{CONCLUSION}

From the results of the discussion above, it can be concluded that adolescents are those aged 13-18 years, at which age a person has passed childhood but is still not mature enough to be considered an adult and in a transitional period. This behaviour will harm himself and those around him. The factors behind the occurrence of juvenile delinquency are internal factors and external factors, internal factors in the form of an identity crisis, external factors such as lack of attention from parents, lack of knowledge about religion, the influence of the surrounding environment and culture. Kind of juvenile delinquency, drugs, drinking alcohol, and getting caught in a fight, causing a disturbance to disturb the public. The absence of parental control makes it easier for children to do whatever they want. Even trapped free sex. Delinquency committed by adolescents due to the absence of attention from parents and the environment towards the development of children's growth, and the inculcation of religious values in the environment where the child grows and develops.

\section{ACKNOWLEDGMENT}

A big thank you goes to the Editor writers Atlantis Releases provide an opportunity for authors to publish this article. Press impossible without the help of Atlantis this article can be published. We wish all those who help authors in publishing this article is rewarded Allah Amin.

\section{REFERENCES}

[1] F. Amalia, Peran Polwiltabes dalam Penanganan Kenakalan Remaja di Kota Semarang (Doctoral dissertation). Universitas Negeri Semarang, 2005 .

[2] P.L. Runcan, C. Constantineanu, B. Ielics and D. Popa, "The role of communication in the parent-child interaction," Procedia-Social and Behavioral Sciences, vol. 46, pp. 904-908, 2012.

[3] H. Poduthase, Parent-adolescent relationship and juvenile delinquency in Kerala, India: A qualitative study (Doctoral dissertation, College of Social Work, University of Utah), 2012.

[4] S.M. Tolou, W. Hadley, S.M. Conrad and L.K. Brown, "The role of family affect in juvenile drug court offenders' substance use and HIV risk," Journal of Child and Family Studies, vol. 21, no. 3, pp. 449-456, 2012 .

[5] Z. Thoyibah, "Correlation Between Family Communication Patterns And Juvenile Delinquency In Junior High School," Belitung Nursing Journal (BNJ), vol. 6, no. 5, 2017

[6] M.C. Gearhart and R. Tucker, "Criminogenic Risk, Criminogenic Need Collective Efficacy, and Juvenile Delinquency," Criminal Justice and Behavior, 0093854820928568, 2020.

[7] N. Unayah and M. Sabarisman, "Fenomena Kenakalan Remaja dan Kriminalitas,” Sosio Informa, vol. 1, no. 2, 2015

[8] M.B. Miles, A.M. Huberman and J. Saldana, Qualitative Data Analysis, A Methods Sourcebook, Edition 3. USA: Sage Publications. Terjemahan Tjetjep Rohindi Rohidi, UI-Press, 2014

[9] S. Sarwirini, "Kenakalan Anak (Juvenile Deliquency) : Kausalitas dan Upaya Penanggulangannya.,'Jurnal Perspektif, vol. XVI, no. 4, 2011.

[10] G. Boeree, Psikologi Sosial. Jokjakarta: Prismasophie, 2008.

[11] F. Fatoni, Proses Penyidikan T erhadap Tindak Pidana Anak di Polres Brebes Pada Tahun 2011-2012 (Studi Kasus Di Polres Brebes). Universitas Islam Negeri Sunan Kalijaga, 2013.

[12] T.H. Liu, S. De Li, X. Zhang and Y. Xia, "The spillover mechanism linking family conflicts and juvenile delinquency among Chinese adolescents," International journal of offender therapy and comparative criminology, vol. 64, no. 2-3, pp. 167-186, 2020.

[13] S. Simanjuntak, Latar Belakang Kenakalan Anak. Jakarta: Gunung, 1995 . 